Journal of Animal and Veterinary Advances 9 (11): 1654-1659, 2010

ISSN: $1680-5593$

(C) Medwell Journals, 2010

\title{
Effect of Legume (Phaseolus calcaratus) Hay Supplementation on Rumen Cellulolytic Bacterial Populations in Swamp Buffaloes Investigated by the Real-Time PCR Technique
}

\author{
${ }^{1,2}$ Vongpasith Chanthakhoun and ${ }^{1}$ Metha Wanapat \\ ${ }^{1}$ Tropical Feed Resources Research and Development Center (TROFREC), \\ Department of Animal Science, Faculty of Agriculture, Khon Kaen University, \\ Khon Kaen 40002, Thailand \\ ${ }^{2}$ Department of Animal Science, Faculty of Agriculture and Forest Resource, \\ Souphanouvong University, Luangprabang, LAO PDR, Thailand
}

\begin{abstract}
A quantitative real-time PCR approach was used to determine the population densities of major ruminal cellulolytic bacterial species (Fibrobacter succinogenes, Ruminococcus albus and Ruminococcus flavefaciens) in rumen fluid and digesta of swamp buffalo (Bubalus bubalis). Four rumen-fistulated, male swamp buffalo were randomly assigned according to a $4 \times 4$ Latin square design to evaluate the effect of Phaseolus calcaratus Hay (PCH) supplementation. PCH contained $18.3 \%$ Crude Protein (CP) and $2.8 \%$ condensed tannins . Animals were given 0,300,600 and $900 \mathrm{~g}_{\text {day }}{ }^{-1}$ as supplements. All animals were given ad libitum access to rice straw while additional concentrate $(12.6 \% \mathrm{CP})$ was given at $0.3 \%$ body mass and each period lasted for 21 days. At the end of each period, rumen fluid and digesta was collected at $0,4 \mathrm{~h}$ post morning feeding. It was found that $\mathrm{PCH}$ supplementation increased these three cellulolytic bacteria $F$. succinogenes between 2.5 and $5.5 \times 10^{9}, R$. flavefaciens between 3.6 and $9.1 \times 10^{9}, R$. albus between 5.7 and $17.9 \times 10^{8}$ copies $\mathrm{mL}^{-1}$ at $0,300,600$ and $900 \mathrm{~g}_{\text {day }}{ }^{-1}$ of supplementation, respectively. Moreover, at $4 \mathrm{~h}$ post-morning feeding, the populations of the two cellulolytic bacteria were higher than those found at $0 \mathrm{~h}$ post-morning feeding. It is most notable that $R$. flavefaciens and $R$. albus were the highest in population in the rumen of swamp buffalo, hence indicating high ability in utilizing high fibrous feeds.
\end{abstract}

Key words: Cellulolytic bacteria, swamp buffalo, fed legumes, supplementation, evalute, determinate, Thailand

\section{INTRODUCTION}

Swamp buffaloes (Bubalus bubalis) are important contributors to meat, draft power, fuel and leather production in many developing countries and able to utilize feed efficiently than cattle where the feed supply is of low quality and the ability to recycle nitrogen to the rumen. Thus, variations between cattle and swamp buffalo in the proportions and number of rumen bacteria, protozoa and fungal zoospores could attribute to the explanation of differences in digestive capability due to fermentation end-products available for absorption and utilization by ruminants (Wanapat and Rowlinson, 2007). There are abundantly available local feed resources for ruminants especially those raised in the tropics (Wanapat, 2008). The complex symbiotic microbiota of the rumen is responsible for breakdown of plant fiber, ability the ruminal host animal's lack, This microbiota is highly responsive to changes in diet, age, antibiotic use and the health of the host animal and varies according to geographical location, season and feeding regimen (Bryant, 1959; Hungate, 1966). However, tropical legumes and browse also contain phenolics other than lignin which limit the digestibility of cell wall carbohydrates and proteins. The presence of tannins in legumes and browse species may also result in binding of proteins and thus inhibit microbial attack and make them an alternative source of by-pass protein to be evaluated as a supplement for ruminant production systems in the tropics. Therefore, anaerobic rumen fibrolytic bacteria, protozoa and fungi degrade fibrous materials allowing ruminants to utilize plant fiber for nutrition. Bacteria are the most numerous of these microorganisms and play a major role in the biological degradation of dietary fiber. Fibrobacter succinogenes, Ruminococcus albus and Ruminococcus flavefaciens are presently recognized as the major cellulolytic bacterial species found in the rumen (Forster et al., 1997; Shinkai and Kobayashi, 2007).

Corresponding Author: Metha Wanapat, Department of Animal Science, Faculty of Agriculture, Khon Kaen University, Khon Kaen 40002, Thailand 
Recent advances in molecular biology techniques allow the analysis of such bacteria without cultivation, thereby identifying many functional but uncultured bacteria as new targets for basic and applied research (Kobayashi, 2006). Moreover, DNA-based methods offer the option of storing samples until their analysis which could be an important advantage under field conditions (Castillo et al., 2006). The recent development of Real-time PCR has been successfully used for quantifying protozoa (Skillman et al., 2006; Sylvester et al., 2004), cellulolytic fungi Denman and McSweeney (2006) and cellulolytic bacterial species (Koike and Kobayashi, 2001; Koike et al., 2003; McSweeney and Denman, 2007). Real-time PCR is an approach that allows continuous monitoring of PCR product formation and techniques vary according to the method of fluorescence generation. Real-time PCR has the ability to enumerate targeted bacteria with high sensitivity Zimmermann and Mannhalter (1996) and has been used to analyze various environmental samples such as water (Leser et al., 1995) and rumen digesta (Reilly and Attwood, 1998). This technique is both reliable and simple to perform. Increased knowledge concerning the rumen cellulolytic bacterial population will allow insight into the fiber digestion capabilities of ruminant animals. Real-time PCR assay development for the cellulolytic rumen bacterial species $F$. succinogenes, $R$. albus and $R$. flavefaciens was reported by Koike and Kobayashi (2001). However, very limited researches have been conducted in swamp buffaloes with regards to ruminal bacterial population using molecular techniques. The project was conducted to study the effects of Phaseolus calcaratus Hay (PCH) on cellulolytic ruminal bacterial populations in swamp buffaloes using the real-time PCR technique.

\section{MATERIALS AND METHODS}

Animals and sample collection: Four, rumen fistulated, Thai-native swamp buffaloes (Bubalus bubalis) about 2.5 years old with $260 \pm 10 \mathrm{~kg}$ body mass were randomly assigned to receive four ratio of Phaseolus Calcaratus Hay $(\mathrm{PCH})$ supplementation $\left(0,300,600\right.$ and $\left.900 \mathrm{~g} \mathrm{day}^{-1}\right)$ according to a $4 \times 4$ Latin square design. All animals were given ad libitum access to rice straw while additional concentrate $(12.6 \% \mathrm{CP})$ was given at $0.3 \%$ body mass (Table 1). All animals were kept in individual pens and received free choice of water and mineral lick-blocks. The experiment was conducted for four periods each period lasted 21 days. At the end of each period, rumen fluid and digesta was collected at $0,4 \mathrm{~h}$ post morning feeding by hands through rumen fistulated buffaloes from the middle part of the rumen and was stored at -20 for DNA
Table 1: Chemical composition of Rice Straw (RS), legume (PCH) and concentrate mixture

\begin{tabular}{|c|c|c|c|}
\hline Item & Concentrate & RS & $\mathrm{PCH}$ \\
\hline \multicolumn{4}{|c|}{ Ingredients, dry mater (\%) } \\
\hline Cassava chip & 63.0 & - & - \\
\hline Rice bran & 15.0 & - & - \\
\hline Palm kernel meal & 15.0 & - & - \\
\hline Molasses & 3.0 & - & - \\
\hline Urea $(46 \% \mathrm{~N})$ & 1.0 & - & - \\
\hline Salt & 1.0 & - & - \\
\hline Sulphur & 1.0 & - & - \\
\hline Mineral mixture & 1.0 & - & - \\
\hline Total & 100.0 & - & - \\
\hline \multicolumn{4}{|c|}{ Chemical composition } \\
\hline DM (\%) & 88.6 & 93.0 & 89.6 \\
\hline \multicolumn{4}{|c|}{ In $\%$ of dry matter } \\
\hline Ash & 5.7 & 14.6 & 10.6 \\
\hline $\mathrm{CP}$ & 12.6 & 2.7 & 18.3 \\
\hline $\mathrm{NDF}$ & 20.8 & 78.4 & 51.2 \\
\hline $\mathrm{ADF}$ & 8.7 & 46.2 & 30.7 \\
\hline CT & - & - & 2.8 \\
\hline
\end{tabular}

RS $=$ Rice Straw, $\mathrm{PCH}=$ Phaseolus calcaratus Hay, $\mathrm{DM}=$ Dry Matter, $\mathrm{OM}=$ Organic Matter; $\mathrm{CP}=$ Crude Protein, $\mathrm{NDF}=$ Neutral-Detergent Fiber, $\mathrm{ADF}=$ Acid-Detergent Fiber, $\mathrm{CT}=$ Condensed Tannins

extraction according to $\mathrm{Yu}$ and Morrison (2004) technique. Feed chemical composition samples were dried at $60^{\circ} \mathrm{C}$ and ground (1 mm screen using Cyclotech Mill, Tecator, Sweden) and then analyzed for DM, ether extract, ash and CP content (AOAC, 1990), NDF and ADF were determined according to Goering and Van Soest (1970).

DNA extraction: Community DNA was extracted from $0.5 \mathrm{~mL}$ aliquots of rumen digesta by the $\mathrm{RBB}+\mathrm{C}$ method as described by $\mathrm{Yu}$ and Morrison (2004). In brief, the cell lysis is achieved by bead beating in the presence of $4 \%$ (w/v) Sodium Dodecyl Sulfate (SDS), $500 \mathrm{mM} \mathrm{NaCl}$ and $50 \mathrm{mM}$ EDTA. The buffer should also protect the released DNA from degradation by DNases which are very active in the rumen and gastrointestinal sample. After bead beating most of the impurities and the SDS are removed by precipitation with ammonium acetate and then the nucleic acids are removed by precipitation with isopropanal. Genomic DNA can then purified via sequential digestion with RNase $\mathrm{A}$ and proteinase $\mathrm{K}$ and the DNA was purified using columns from QIAgen DNA Mini Stool Kit (QIAGEN, Valencia, CA).

Real-time PCR: The primers used for the real-time PCR are as follows: primers for Fibrobactor succinogenes, Fs219f (5'-GGT ATG GGA TGA GCT TGC-3') and Fs654r (5'-GCC TGC CCC TGA ACT ATC-3') were selected to allow amplification (446 bp product) of all $10 \mathrm{~F}$. succinogenes strains deposited in GenBank. For Ruminococcus albus primers, Ra1281f (5'-CCC TAA AAG CAG TCT TAG TTCG-3') and Ral 439r ( $5^{\prime}$ CCT CCT TGC GGT TAG AAC A-3') (175 bp product). Ruminococcus flavefaciens primers, Rf154f (5'-TCT GGA AAC GGA TGG 
TA-3') and Rf425r (5'-CCT TTA AGA CAG GAG TTT ACA A-3') were also selected to allow species-species amplification (295 bp) of all seven $R$. flavefaciens strains deposited in GenBank. All these primer sets were previously published by Koike and Kobayashi (2001). Real-time PCR amplification and detection were performed using a Choromo 4 detection system (Bio-Rad, Hercules, $\mathrm{CA}$ ). The reaction was conducted in a final volume of $10 \mu \mathrm{L}$ containing the following: $5.1 \mu \mathrm{L}$ Quatimix EASY SYG Kit (BIOTOOLS B and M Labs, S.A.), $0.408 \mu \mathrm{L}$ as a forward primer, $0.408 \mu \mathrm{L}$ as a reverse primer, $2.244 \mu \mathrm{L}$ distilled water and $2 \mu \mathrm{L}$ of DNA solution of unknown concentration. PCR conditions for $F$. succinogenes were as follows: $30 \mathrm{sec}$ at $94^{\circ} \mathrm{C}$ for denaturing, $30 \mathrm{sec}$ at $60^{\circ} \mathrm{C}$ for annealing and $30 \mathrm{sec}$ at $72^{\circ} \mathrm{C}$ for extension ( 48 cycles), except for $9 \mathrm{~min}$ of denaturation in the first cycle and $10 \mathrm{~min}$ of extension in the last cycle. Amplification of $16 \mathrm{~S}$ rRNA genes for $R$. flavefaciens and $R$. albus was carried out similarly except at an annealing temperature of $55^{\circ} \mathrm{C}$. To determine the specificity of amplification, an analysis of the product melting curve was performed after the last each cycle of amplification.

A sample-derived standard was prepared from the treatment pool set of community DNA instead of amplifying the target genes from individual community DNA samples and then pooling the PCR products. Then the PCR product was purified using a QIA quick PCR purification kit (QIAGEN, Inc., Valencia, CA) and quantified using spectrophotometry. For each sample derived standard, the copy number concentration was calculated based on the length of the PCR product and the mass concentration. Ten-fold serial dilutions were made in Tri-EDTA prior to real-time PCR. In total, three real-time PCR standards were prepared. The conditions of the real-time PCR assays of target genes were the same as those of the regular PCR described earlier. The Biotools QuantiMix EASY SYG KIT (B and M Labs, S. A., Spain) was used for real-time PCR amplification. All PCRs were performed in duplicate.

Statistical analysis: Statistical analyses were performed using Proc GLM (Statistical Analysis Systems, 1996) mean separations with a significant $(\mathrm{p}<0.05)$ for treatments were statistically compared using the Duncan's New Multiple Range Test (DMRT).

\section{RESULTS AND DISCUSSION}

External standards for real-time PCR were prepared from a simulated rumen matrix. For each standard, linear regressions derived from the threshold cycle $[\mathrm{C}(\mathrm{T})]$ of each DNA dilution versus the log quality (Fig. 1) were
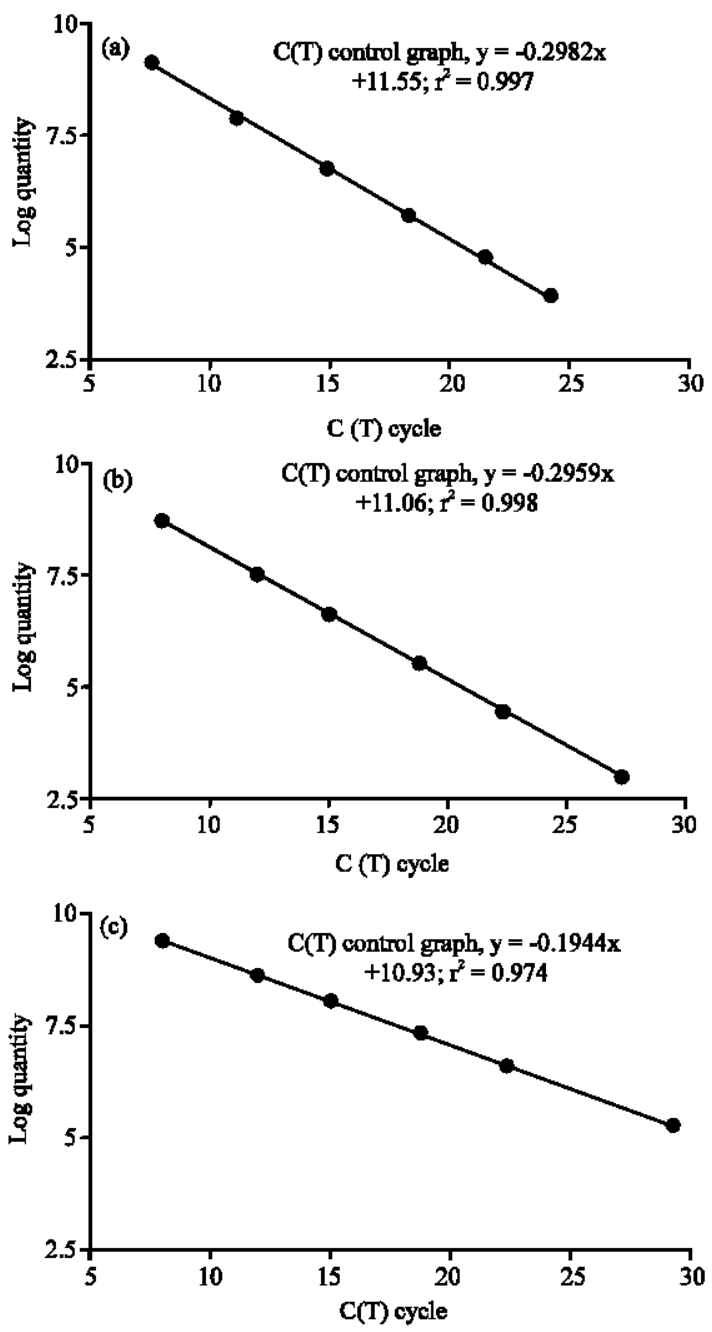

Fig. 1: Standard curve obtained by plotting the logarithm of the DNA concentration for $F$. succinogene (a), $R$. favefaciens (b) and R. albus (c) vs. threshold cycle (Ct) mean values. The curve was constructed using data from all the eight triplicate standards amplifications

calculated. Logarithms of the DNA concentration (copies $\mathrm{mL}^{-1}$ ) were plotted against the calculated means (Fig. 1) obtaining a straight line of equations $y=-0.2982 x$ $+11.55, y=-0.2959 x+11.06$ and $y=-0.1944 x+10.93$ (where $\mathrm{y}$ is the $\log$ of DNA concentration and $\mathrm{x}$ is the $\mathrm{Ct}$ ) with a linear correlation coefficient $\left(\mathrm{r}^{2}\right)$ of $0.997,0.998$ and 0.974 for F. succinogenes (Fig. 1a), R. flavefaciens (Fig. 1b) and $R$. albus (Fig. 1c), respectively. The equations were used to quantify DNA from rumen digesta samples. Table 1 and 2 shows data on chemical composition of experimental feeds and cellulolytic bacterial population obtained by real-time PCR technique. Concentrate mixture 
Table 2: Quantification of cellulolytic bacterial DNA from rumen sampling hours using Real-time PCR technique as influenced by the PCH supplementation in swamp buffalo

\begin{tabular}{|c|c|c|c|c|c|c|c|c|}
\hline \multirow[b]{2}{*}{ Item } & \multicolumn{4}{|c|}{ Treatments } & \multirow[b]{2}{*}{ SEM } & \multicolumn{3}{|c|}{ Contrasts } \\
\hline & 0 & 300 & 600 & 900 & & $\mathrm{~L}$ & $\mathrm{Q}$ & $\mathrm{C}$ \\
\hline \multicolumn{9}{|c|}{ F. succinogenes $\times 10^{9}$ copies $\mathrm{mL}^{-1}$} \\
\hline $0 \mathrm{~h}$-post feeding & 2.6 & 3.9 & 6.7 & 2.6 & 1.4 & NS & NS & NS \\
\hline 4 & 2.4 & 3.4 & 4.3 & 3.3 & 0.4 & NS & * & NS \\
\hline Mean & $2.5^{\mathrm{a}}$ & $3.7^{\mathrm{ab}}$ & $5.5^{b}$ & $3.0^{\mathrm{a}}$ & 0.7 & NS & * & NS \\
\hline \multicolumn{9}{|c|}{ R. flavefaciens $\times 10^{9}$ copies $\mathrm{mL}^{-1}$} \\
\hline $0 \mathrm{~h}$-post feeding & 3.9 & 3.7 & 6.1 & 8.5 & 1.6 & 0.06 & NS & NS \\
\hline 4 & $6.1^{\mathrm{a}}$ & $3.6^{\mathrm{a}}$ & $7.6^{6}$ & $9.6^{b}$ & 1.3 & * & NS & NS \\
\hline Mean & $5.0^{\mathrm{a}}$ & $3.6^{\mathrm{ab}}$ & $6.9^{a}$ & $9.1^{\mathrm{c}}$ & 0.9 & * & NS & NS \\
\hline \multicolumn{9}{|c|}{ R. albus $\times 10^{8}$ copies $\mathrm{mL}^{-1}$} \\
\hline $0 \mathrm{~h}$-post feeding & 2.7 & 3.8 & 5.6 & 12.3 & 3.6 & NS & NS & NS \\
\hline 4 & 8.8 & 13.8 & 7.4 & 23.5 & 5.4 & NS & NS & NS \\
\hline Mean & $5.7^{\mathrm{a}}$ & $8.8^{\mathrm{a}}$ & $6.5^{\mathrm{a}}$ & $17.9^{b}$ & 2.4 & . & NS & NS \\
\hline
\end{tabular}

a,b,c Means in the same row with different superscripts differ $(\mathrm{p}<0.05)$; T1: 0 (Control), T2: $300 \mathrm{~g}, \mathrm{~T} 3: 600 \mathrm{~g}, \mathrm{~T} 4: 900 \mathrm{~g} / \mathrm{hd} / \mathrm{day}, \mathrm{PCH}, \mathrm{SEM}=$ Standard Error of Mean. L: Linear, Q: Quadratic, C: Cubic

was formulated to contain carbohydrate and protein sources using cassava chip and oil-crop meals resulting in $12.6 \% \mathrm{CP}$ and $20.8 \% \mathrm{NDF}$, respectively. Meanwhile, rice straw and Phaseolus calcaratus Hay $(\mathrm{PCH})$ contained 2.7 and $18.3 \% \mathrm{CP}, 51.2 \% \mathrm{NDF}$, respectively. In addition, $\mathrm{PCH}$ had $2.8 \%$ condensed tannins. Three predominant cellulolytic bacterial population namely, $F$. succinogenes, $R$. flavefaciens and $R$. albus were quantified by real-time PCR technique using DNA extracted from rumen fluid and digesta sampled at 0 and $4 \mathrm{~h}$ post morning feeding.

There was an increasing trend for the two species except for one species after feeding times especially for $R$. flavefaciens. Supplementation level of PCH resulted in increased population of $F$. succinogenes quadratically while in $R$. flavefaciens and $R$. albus were increased linearly. These findings suggest that $\mathrm{PCH}$ had provided addition of both physical and chemical sources enabling these bacteria to grow favourably. Significant increases were found in $R$. flavefaciens and $R$. albus when $\mathrm{PCH}$ were supplemented at 600 and $900 \mathrm{~g}$ day $^{-1}$. However, when determined by total means there were increasing trends for all bacteria species after feeding times.

High level of $\mathrm{PCH}$ increased cellulolytic bacteria numbers in the rumen fluid and digesta (Table 2) which could be related to the effect of condensed tannin $(2.8 \%$ in the DM). However, Hart and Wanapat (1992) who compared Untreated Rice Straw (URS) and Urea Treated (5\%) Rice Straw (UTRS) in swamp buffaloes, it was revealed that Organic Matter (OM) digestibility and voluntary $O M$ intake were significantly improved by 17 and $25 \%$, respectively. In addition, rumen retention time was decreased by $34 \%$ indicating pronounced activities of rumen cellulolytic bacteria. In another trial by Chanjula et al. (2004) increasing level of cassava hay in rice straw based-diet dramatically decreased rumen protozoa $\left(6.2-2.1 \times 10^{5}\right.$ cell $\mathrm{g}^{-1}$ rumen) while cellulolytic bacteria exhibited an increasing trend from 5.3-7.2 $\times 10^{7} \mathrm{CFU} \mathrm{g}^{-1}$ rumen. The effects were attributed by cassava hay containing higher protein $(25 \%)$ and condensed tannins (4\%). On the other hand, the studies conducted to investigate effect of urea level on energy sources by Wanapat et al. (2009) and effect of roughage to concentrate ratio by Wanapat and Cherdthong (2009), reported that in swamp buffalo using PCR-DGGE and Real-time PCR techniques, it was found that population of predominant cellulolytic bacteria were higher in population of $F$. succinogenes, $R$. flavefaciens and $R$. albus in both rumen fluid and digesta, respectively.

The dynamics of truly cellulolytic rumen bacteria were in good correlation with response to diet shift particularly increasing level of concentrate and the application of Real-time PCR technique allowed an investigation on possible changes in the number of cellulolytic bacterial species in vivo (Mosoni et al., 2007). In another experiment, it was found that reduced rumen protozoal numbers, increased bacterial numbers, significantly reduced ammonia nitrogen, higher daily body weight gain and improved feed conversion efficiency (Russell and Rychlik, 2001). Currently, Khiaosa-Ard et al. (2009) have shown effective result of condensed tannins on reducing rumen protozoa and increasing bacterial population. Moreover, condensed tannins has been shown to bind to the terminal end of linoleic acid and hence, reducing bihydrogenation and elevating levels of conjugated linoleic acid in lower-gut. Moreover, rumen $\mathrm{pH}$, together with microbial population, nature of substrates, environmental factors such as temperature and existence of cations and soluble carbohydrates have been suggested as factors governing bacterial attachment of feed particles (Miron et al., 2001). Ruminal $\mathrm{pH}$ is one of the most important of these factors because cellulolytic bacteria are very sensitive to $\mathrm{pH}$ changes (Sung et al., 2007). When ruminants fed with fiber-deficient rations, ruminal $\mathrm{pH}$ declines, microbial ecology is altered and the animals become more susceptible to metabolic disorders (Russell and Rychlik, 2001). As Koike et al. (2003) quantified cell numbers of $F$. succinogenes, $R$. flavefaciens and $R$. albus which attached to straw by competitive PCR and illustrated that numbers of all three species increased gradually with increased NDF disappearance. On the other hand, Wora-Anu et al. (2000) reported that roughage to concentrate ratio at 100: 0,60 : 40 and 40: 60 could decrease cellulolytic bacterial population in swamp buffalo $\left(5.62,4.06\right.$ and $4.57 \times 10^{10}$ $\mathrm{CFU} \mathrm{mL}^{-1}$ ), respectively. Furthermore, when urea-treated rice straw was solely fed the three cellulolytic bacteria numbers were increased up to $2.65 \times 10^{9}$ and $3.54 \times 10^{9}$ copies per milliliter for $F$. succinogenes, $5.10 \times 10^{7}$ and 
$7.40 \times 10^{7}$ copies $\mathrm{mL}^{-1}$ for $R$. flavefaciens and $4.00 \times 10^{6}$ and $6.00 \times 10^{6}$ copies $\mathrm{mL}^{-1}$ for $R$. albus in rumen fluid and digesta, respectively. The distribution of the three cellulolytic bacteria species in digesta were highest at $3.21 \times 10^{9}, 4.55 \times 10^{7}$ and $4.56 \times 10^{6}$ copies $\mathrm{mL}^{-1}$ for $F$. succinogenes, $R$. flavefaciens and $R$. albus, respectively as reported by Wanapat and Cherdthong (2009). In the study by Koike et al. (2003) who suggested that the increase in attached cell numbers observed could be mostly attributed to cell proliferation on the straw after $6 \mathrm{~h}$, the numbers of attached cells of the three species gradually increased and peaked at $24 \mathrm{~h}\left(10^{9} \mathrm{~g}^{-1}\right.$ DM for $F$. succinogenes and $10^{7} \mathrm{~g}^{-1} \mathrm{DM}$ for $R$. flavefaciens $)$ or $48 \mathrm{~h}\left(10^{6} \mathrm{~g}^{-1} \mathrm{DM}\right.$ for $R$. albus $)$. There are two possible explanations of the increased cell populations on $4 \mathrm{~h}$ post-feeding; one is cell proliferation after feeding and additional attachment of new bacteria from the liquid phase or from other particles. More data found under this study are shown in Table 2.

\section{CONCLUSION}

Based on this study, it was found that $\mathrm{PCH}$ supplementation between 600-900 g/hd/day could improve higher cellulolytic bacterial population in swamp buffaloes. Moreover, applicability of Real-time PCR technique for quantification of cellulolytic bacterial species ( $F$. succinogenes, R. albus and R. favefaciens) in the rumen fluid and digesta of swamp buffaloes could offer useful information. As found, $R$. flavefaciens and $R$. albus were the most predominant of the three species as influenced by $\mathrm{PCH}$ supplementation in the rumen of swamp buffalo.

\section{RECOMMENDATIONS}

Therefore, legume supplementations such as those of $\mathrm{PCH}$ were useful sources in enhancing rumen ecology and subsequent fermentation.

\section{ACKNOWLEDGEMENTS}

The researchers wish to express sincere thanks to the Tropical Feed Resources Research and Development Center (TROFREC), Khon Kaen University, Thailand and to the Thailand Research Fund Master Degree Research Grants: TRF-MAG and Khon Kaen University for providing financial support of research, research facilities and experimental animals. Laboratory equipment provided by the Agricultural Biotechnology Research Center, Faculty of Agriculture, Khon Kaen University, Thailand was greatly appreciated.

\section{REFERENCES}

AOAC, 1990. Official Methods of Analysis. 15th Edn., Association of Official Analytical Chemists, Washington, DC., USA., pp: 200-210.

Bryant, M.P., 1959. Bacterial species of the rumen. Bacteriol. Rev., 23: 125-153.

Castillo, M., M.S. Martin-Orue, E.G. Manzanilla, I. Badiola and M.J. Gasa, 2006. Quantification of total bacteria, enterobacteria and lactobacilli populations in pig digesta by real-time PCR. Vet. Microbiol., 114: $165-170$.

Chanjula, P., M. Wanapat, C. Wachirapakorn and P. Rowlinson, 2004. Effect of various levels of cassava hay on rumen ecology and digestibility in Swamp buffaloes. Asian-Aust. J. Anim. Sci., 17: 663-669.

Denman, S.E. and C.S. McSweeney, 2006. Development of a real time PCR assay for monitoring anaerobic fungal and cellulolytic bacterial populations within the rumen. FEMS Microbiol. Ecol., 58: 572-582.

Forster, R.J., J. Gong and R.M. Teather, 1997. Groupspecific 16S rRNA hybridization probes for determinative and community structure studies of Butyrivibrio fibrisolvens in the rumen. Applied Environ. Microbiol., 63: 1256-1260.

Goering, H.K. and P.J. van Soest, 1970. Forage Fiber Analysis (Apparatus, Reagents, Procedures and Some Applications). Agricultural Handbook 379, Agricultural Research Service, United States Department of Agriculture, Washington, DC., pp: $1-20$.

Hart, F.J. and M. Wanapat, 1992. Physiology of digestion of urea-treated rice straw in swamp buffalo. AsianAust. J. Anim. Sci., 5: 617-622.

Hungate, R.E., 1966. The Rumen and its Microbes. Academic Press, New York.

Khiaosa-Ard, R., S.F. Bryner, M.R.L. Scheeder, H.R. Wettstein, F. Leiber, M. Kreuzer and C.R. Soliva, 2009. Evidence for the inhibition of the terminal step of ruminal á-linolenic acid biohydrogenation by condensed tannins. J. Dairy Sci., 92: 177-188.

Kobayashi, Y., 2006. Inclusion of novel bacteria in rumen microbiology: Need for basic and applied science. Anim. Sci. J., 77: 375-385.

Koike, S. and Y. Kobayashi, 2001. Development and use of competitive PCR assays for the rumen cellulolytic bacteria: Fibrobactor succinogenes, Ruminococcus albus and Ruminococcus flavefaciens. FEMS Microbiol. Lett., 204: 361-366. 
Koike, S., J. Pan, Y. Kobayashi and K. Tanaka, 2003. Kinetics of in sacco fiber-attachment of representative ruminal cellulolytic bacteria monitored by competitive PCR. J. Dairy Sci., 86: 1429-1435.

Leser, T.D., M. Boye and N.B. Hendriksen, 1995. Survival and activity of a Pseudomonas sp. strain B13 (FR1) in a marine microcosm determined by quantitative PCR and an rRNA-targeting probe and its effect on the indigenous bacterioplankton. Applied Environ. Microbiol., 61: 1201-1207.

McSweeney, C.S. and E. Denman, 2007. Effect of sulfur supplements on cellulolytic rumen micro-organisms and microbial protein synthesis in cattle fed a high fibre diet. J. Applied Microbiol., 103: 1757-1765.

Miron, J., D. Ben-Ghedalia and M. Morrison, 2001. Invited review: Adhesion mechanisms of rumen cellulolytic bacteria. J. Dairy Sci., 84: 1294-1309.

Mosoni, P., F.C. Durand, C.B. Maillet and E. Forano, 2007. Quantification by Real-time PCR of cellulolytic bacteria in the rumen of sheep after supplementation of a forage diet with readily fermentable carbohydrates: Effect of a yeast additive. J. Applied Microbiol., 103: 2676-2685.

Reilly, K. and G.T. Attwood, 1998. Detection of clostridium proteoclasticum and closely related strains in the rumen by competitive PCR. Applied Environ. Microbiol., 64: 907-913.

Russell, J.B. and J.L. Rychlik, 2001. Factors that alter rumen microbial ecology. Science, 292: 1119-1122.

Shinkai, T. and Y. Kobayashi, 2007. Localization of ruminal cellulolytic bacteria on plant fibrous materials as determined by fluorescence in situ hybridization and real-time PCR. Applied Environ. Microbiol., 73: 1646-1652.

Skillman, L.C., A.F. Toovey, A.J. Williams and A.D. Wright, 2006. Development and validation of a real-time PCR method to quantify rumen protozoa and examination of variability between entodinium populations in sheep offered a hay-based diet. Applied Environ. Microbiol., 72: 200-206.
Statistical Analysis Systems, 1996. SAS Users Guide: Statistics. 5th Edn., SAS Institute for Statistical Analysis, Cary, USA.

Sung, H.G., Y. Kobayashi, J. Chang, A. Ha, H. Hwang and J.K. Ha, 2007. Low ruminal $\mathrm{pH}$ reduces dietary fiber digestion via reduced microbial attachment. AsianAust. J. Anim. Sci., 20: 200-207.

Sylvester, J.T., S.K. Karnati, Z. Yu, M. Morrison and J.L. Firkins, 2004. Development of an assay to quantify rumen ciliate protozoal biomass in cows using real-time PCR. J. Nutr., 134: 3378-3384.

Wanapat, M. and A. Cherdthong, 2009. Use of real-time PCR technique in studying rumen cellulolytic bacteria population as affected by level of roughage in Swamp buffalo. Curr. Microbiol., 58: 294-299.

Wanapat, M. and P. Rowlinson, 2007. Nutrition and feeding of swamp buffalo: Feed resources and rumen approach. Proceedings of the 8th World Buffalo Congress, Oct. 19-22, Caserta, Italy, pp: 67-73.

Wanapat, M., 2008. Potential uses of local feed resources for ruminants. Trop. Anim. Health. Prod., 41: 1035-1049.

Wanapat, M., R. Pilajun and P. Kongmun, 2009. Ruminal ecology of swamp buffalo as influenced by dietary sources. Anim. Feed Sci. Tech., 151: 205-214.

Wora-Anu, S., M. Wanapat, C. Wachirapakorn and N. Nuntaso, 2000. Effects of roughage to concentrate ratio on ruminal ecology and voluntary feed intake in cattle and swamp buffaloes fed on urea-treated rice straw. Asian Aust. J. Anim. Sci., 13: 236-236.

$\mathrm{Yu}, \mathrm{Z}$. and M. Morrison, 2004. Improved extraction of PCR-quality community DNA from digesta and fecal samples. Bio Technol., 36: 808-812.

Zimmermann, K. and J.W. Mannhalter, 1996. Technical aspects of quantitative competitive PCR. Biotechniques, 21: 268-279. 